\title{
STYLE AND PERSONHOOD: THE CASE OF THE AMASIS PAINTER
}

James Whitley ${ }^{\star}$

School of History, Archaeology and Religion, Cardiff University, UK

For archaeologists discussion of style is unavoidable. Within classical archaeology 'style' is closely associated with connoisseurship as practised by J. D. Beazley. Style identifies individuals, artistic personalities such as the Amasis Painter. This notion of style necessarily overlaps with another debate within both anthropology and prehistoric archaeology (personhood) which also touches on an older discussion within classical studies. These two debates have remained strangers to each other. The article explores these issues in relation to the iconography of hares and arming scenes. Notions of personhood and agency force us to re-evaluate such iconography and its effectiveness as narrative.

\section{Introduction: the centrality of style}

'Style' is an indispensable term within archaeology. It has been argued, with some force, that without an implicit 'theory of style' the practice of both archaeology and art history would be impossible. ${ }^{\mathrm{I}}$ That is not to say that there is an agreed definition as to what the term means, since 'style' operates on several scales. ${ }^{2}$ At the largest scale (what we might call the 'macro-scale') there is, for example, the La Tène art style of Iron Age Europe (usually thought of as Celtic). ${ }^{3}$ At this level style is seen as an expression of a wider cultural (or perhaps less certainly) ethnic group. Notions of 'Greek Art', it could be

\footnotetext{
* Email: WhitleyA@Cardiff.ac.uk
}

This article stems from a talk I gave in Oxford on the I May 20I7, in a seminar series on 'style'. I would like to thank Peter Stewart for inviting me, largely it seems on the basis that I once (long ago) produced a book with the word 'style' in the title. Peter assured me that not having thought much about style for a very long time was not an impediment to my being there. At the very least I can say that my talk had a cast of very distinguished Oxonians, who have (at various points) commented on either style or personhood. In revising my paper for publication, I have taken advantage of advice from Laurence Totelin (on hares), of the comments of Robin Osborne, Anthony Snodgrass and the two anonymous CCJ referees on earlier drafts, and I am also (as ever) grateful to Kirsty Harding for preparing some fine illustrations.

I Neer (20I0) 6-II.

2 See Gell (i998a) i55-9.

3 As in Jacobsthal (I944). 
argued, depend on a notion of Greek style - since, whatever Greek art is, it is not simply the sum total of art objects produced by Greek speakers. ${ }^{4}$ Within the narrower confines of the archaic Aegean most of us are reasonably well acquainted with the regional styles of Orientalizing pottery in the seventh century BC - we talk quite easily of the East Greek 'Wild Goat' style, or Knossian Orientalizing, or Protocorinthian or Protoattic. ${ }^{5}$

Scholars of Attic vase painting however are perhaps more familiar with another definition, forcefully put by J. D. Beazley:

The phrase 'in the style of is used by some where I should write 'in the manner of'; this has warrant, but I was brought to think of 'style' as a sacred thing, as the man himself. ${ }^{6}$

Style is then what allows us to distinguish the work of one person (one painter) from another. Defining individual style is what connoisseurship and attribution is supposed to be all about. Insofar as there is a theory underlying this it is the idea that unconscious tricks of draughtsmanship - the way in which those fussy details such as eyes, ears, noses and chins are drawn - betray the presence of an individual, a definable 'artistic personality'. This certainly works for Beazley's most celebrated case, the Berlin Painter the first painter to be clearly distinguished by this means from his contemporary the Kleophrades Painter. ${ }^{7}$

In the case of the Amasis Painter however one could argue that it is as much iconography as the 'tricks of draftsmanship' (style) that characterises this particular artistic personality. Strictly speaking, of course, the Amasis Painter (the painter who worked closely with the potter Amasis, and who was almost certainly the same person) has been defined partly through those vases signed AMA $\Sigma$ I $\Sigma$ MEחOIE $\Sigma E N$, but more generally through Beazley's and Karouzou's attributions. ${ }^{8} \mathrm{He}$ (and let us go with 'he' for the time being) is thought to be responsible for around I40 vases datable to the mid-sixth century BC. ${ }^{9}$ His main vehicle was not so much the krater (of which we have only a few examples) as the amphora (both the neck amphora and the belly amphora). He is also responsible for a

4 Defining Greek 'style' and art is less straightforward than one might think, especially in relation to 'the Orient'. See now the excellent discussion by Martin (2017).

5 Cook (I972) 4I-I6o remains fundamental to these definitions.

6 Beazley, ABV x (emphasis added).

7 Beazley (I9II), (I922). See now Padgett (2017). The debate on the role of attribution and connoisseurship within classical archaeology is now a developed one. Milestones in this discussion include Kurtz (I985); Beard (I99I); Neer (1997); Whitley (I997); Lynch (2017).

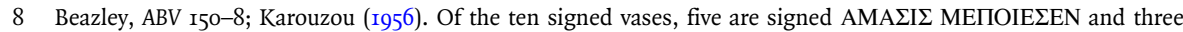
$\mathrm{AMA} \Sigma \mathrm{I} \Sigma$ EПOIE $\Sigma \mathrm{EN}$; on two others the full inscription is missing. Sapirstein (20I3, 50I; 20I4) reckons that the potter Amasis and the painter must be one and the same (see also Hurwit (2015) 79 and r8o n. 3I). The whole question of the 'foreign' connotations of the name Amasis (Boardman (I987)) is not germane to my argument.

9 Beazley (ABV I50-8 and 697-8) lists ninety-two vases; Karouzou (1956) only seventy-eight (including one krater (no. 29) not in Beazley's lists). Sapirstein (2013; 2014) gives a maximum of 145 vases which can be attributed to the Amasis Painter, of which five are uncertain. 
number of cups with a very distinctly non-heroic subject matter. As painter working in the mid-sixth century he is thought of as being in some way in competition with his contemporaries, Lydos and Exekias. ${ }^{\text {IO }}$ The consensus is that, while 'Amasis' is as fine a painter as Lydos (and perhaps a more interesting one), he was not quite as good as Exekias in the two things that matter most to traditional classical archaeologists - the development of visual narrative and the development of more anatomically accurate renderings of the human figure. As John Boardman puts it:

The delicate touch and wit of the Amasis painter are an excellent foil to the workmanlike Lydos or the more statuesque dignity of Exekias. ${ }^{\text {II }}$

This is a nice way of saying that the Amasis Painter seems to have had a greater interest than other painters in rather outré subjects, such as Dionysiac scenes with numerous satyrs and pictures of satyrs $\delta \varepsilon \varphi$ ó $\mu \varepsilon v o r .{ }^{\mathrm{I} 2}$ It is also, of course, a way of damning with faint praise - he is a fine painter, but no Exekias - not the master of narrative compression that we can see in the scene of Achilles and Ajax playing dice, or the 'suicide of Ajax' on a vase once in Boulogne. ${ }^{\mathrm{I}}$

This comparison may be unfair (as I hope to show towards the end of this article). What I want to emphasise here is the manner in which Boardman describes the Amasis Painter - as a defined, bounded individual, not only responsible for but more or less co-extensive with that body of painted pots that have been attributed to him. Boardman uses the active indicative throughout, with 'the Amasis Painter' and 'he' as the subject. This, you might say, is merely a matter of common sense. For were not vase painters individuals?

That depends of course on how we use the term 'individual'. I am not seeking, in this paper, to undermine the general principle of attribution; most of Beazley's attributions have stood up pretty well, when looked at from different perspectives. ${ }^{\mathrm{I}}$ Painters were certainly persons. But that does not quite make them individuals in the modern sense, as bounded entities - especially not in the judicial sense as the ultimate locus of responsibility and agency. Beazley himself was not quite so 'commonsensical' when it came to the Amasis Painter:

Io This at least seems to be the view of most of the contributions to True (I987), i.e. Mertens (I987); Moore (I987); Robertson (I987); Stewart (I987).

II Boardman (I975) 54; general discussion on Amasis and the Amasis Painter: ibid., 52 and 54-6.

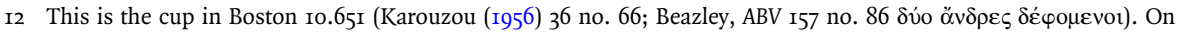
Dionysiac scenes see Carpenter (I986); Heinrichs (I987). Carpenter makes it clear that we would probably not have a developed iconography of satyrs without the Amasis Painter.

I4 That is, when we try to look 'underneath' the apparent straightforward nature of attribution and explore the implicit theoretical assumptions underlying Beazley's practice. Attempts to do this (e.g. Whitley (I997)) have often be misconstrued as being 'anti-Beazley' (as in Oakley (1998), (2009)). For useful recent discussions see Arrington 2017; Lynch 2017. 
He has much in common with the Heidelberg Painter, surpassing him, however, in all respects; a good deal also of Kleitias, if not the finest part, has passed into him lightness, elegance, and precise technique. ${ }^{15}$

Now one might say that this use of the passive, and the idea that a part of another painter 'has passed into him', might be seen as just a façon de parler, an aspect of Beazley's 'scholarly personality' - his style, as it were. Even so, this turn of phrase is not casual - Beazley was notably fastidious in everything he did, especially the way he wrote. If he was ever ambiguous he was purposefully so. His form of words moreover is strikingly similar to the way in which modern anthropologists talk, not about individuals, but partible and permeable persons - so-called 'dividuals' (see below). And it is also in keeping with some of Beazley's more famous bons mots:

My attributions have often been misquoted. I may perhaps be allowed to point out that I make a distinction between the vase by a painter and a vase in his manner; and that 'manner', 'imitation', 'following', 'school', 'circle', 'group', 'influence', 'kinship' are not, in my vocabulary, synonyms. ${ }^{16}$

Beazley here is being characteristically precise in his terms (as he is with others, such as the distinction between 'type' and 'specimen'). We are, after all, being instructed as much in the use of proper vocabulary as in the proper use of the book he has written. And yet it is not immediately clear - at least to me - how we should take his words. To put it at its most 'theoretical', is this statement an epistemological statement or an ontological one? It has mainly been read as epistemological - in an ideal world we would be able to attribute every piece to a definable individual, and the fact that we cannot is simply an indication of the limits of our current state of knowledge. Much excellent recent scholarship (building on Beazley's attributions) has sought more accurate estimates of the numbers of potters and painters working in archaic and classical Athens, for perfectly good historical reasons. ${ }^{17}$ Philip Sapirstein in particular has emphasised that the some of the painters defined by Beazley are more individual than others; some, like the Amasis Painter, the Berlin Painter and Exekias, are well-defined 'artistic personalities'; others are simply hands, where a small number of vases can be grouped by individual style. Sapirstein argues that several of these 'hands' (with only six or so vases attributed to them) might represent the work of the same painter. This suspicion is borne out by one black-figure painter, Sakonides (a contemporary of the Amasis Painter), of whom Beazley says:

I5 Beazley (I986) 52 (emphasis added; see ibid., 52-7 for more on the 'style' of the Amasis Painter).

I6 Beazley, ABV x ('Instructions for use').

17 Sapirstein (2013), (2014); contra Cook (1972) 270-8. Arrington's (2017, 30-2) concern with 'fuzzy edges' does not, in my view, undermine the main thrust of Sapirstein's argument. 
The cups with this painter's signature divide into three groups. Without the signature no one would have guessed the three groups to be by one hand. ${ }^{\mathrm{I} 8}$

Many of these 'hands' should therefore be combined to give a more accurate picture of the number of craftsmen working in Athens in ancient times.

The significance of this distinction between artistic personalities and hands however goes beyond its utility in arriving at better, more accurate, estimates of the size of the Athenian pottery industry. For if we see this as a purely epistemological problem we would expect to be able to refine our attributions and eventually be able to relate almost all Attic vases to particular painters. An epistemological problem would become simply a problem of method: eventually all 'hands' would become definable 'artistic personalities'. Is this really the case? Perhaps. But if so, it is interesting that we can more easily attribute vases to definable 'artistic personalities' in some areas of Greek archaeology than in others. Attribution to 'individuals' is much easier in the study of Attic vase painting than it is within the study of Protocorinthian, and this is not because of lack of either evidence or of scholarly effort. Somehow Protocorinthian vases yield fewer 'individuals' who are painters than do Athenian ones. ${ }^{19}$ Even within Attic black figure there are some groups which are more resistant to attribution than others - the Tyrrhenian Group (for example) remains stubbornly a group, not a set of painters or workshops. ${ }^{20}$

It may be helpful here to illustrate my argument, not in the normal way of providing examples of vases being discussed, but by expressing Beazley's statements in pictorial form, as Venn diagrams. Figure I shows his view of the Amasis Painter and his relations with Kleitias and the Heidelberg Painter. In Figure 2 Beazley's words in his 'instructions for use' become a series of concentric circles with 'style' at the centre, and kinship at the periphery. But these pictures do not quite resolve the ambiguity of his words. In some ways they highlight what may be called the ontological/epistemological dilemma.

I propose to read Beazley's statements 'ontologically', as saying something about the painters themselves, and their entanglements with both other persons and other things. ${ }^{2 \mathrm{I}}$ But to do this I first have to explain what the debate on personhood is all about.

I8 Beazley, $A B V$ i70. To clarify, each of the three groups ( $A B V$ I70-3) has at least one cup signed $\Sigma$ AKONI $\triangle$ ЕЕЕГРАФГEME, though none of them share the same 'style'. Sakonides was a 'Little Master' cup painter (Beazley (1932)).

I9 Shanks (I996) 35. Of the painters defined by Dunbabin and Robertson (1953) only the Sacrifice Painter and the Macmillan Painter (Amyx's Chigi Painter) can be seen to have 'authored' more than ten vases - putting them in Sapirstein's category of 'hands' rather than artistic personalities. The same is true of the numerous 'groups' of Corinthian painters isolated by Amyx (1988, 757-6r). Few if any would pass Sapirstein's test for an 'artistic personality'. See now remarks by Arrington (2017, 30-2 and 35-6).

20 Beazley, ABV 94-Io6. There are groups within the Tyrrhenian Group, but only one painter (the Goltyr Painter), in Sapirstein's terms more a 'hand' than an 'artistic personality'. Beazley (1986) does not even deign to mention the group in his general account of the development of black figure.

2I I should clarify that I do not quite mean 'ontology' in Descola's (2013) sense (as one of his four ontologies). But I do mean it in a related sense that does not correspond to its general use in philosophy - as a statement about a particular (cultural and historical) relationship between persons and things. 


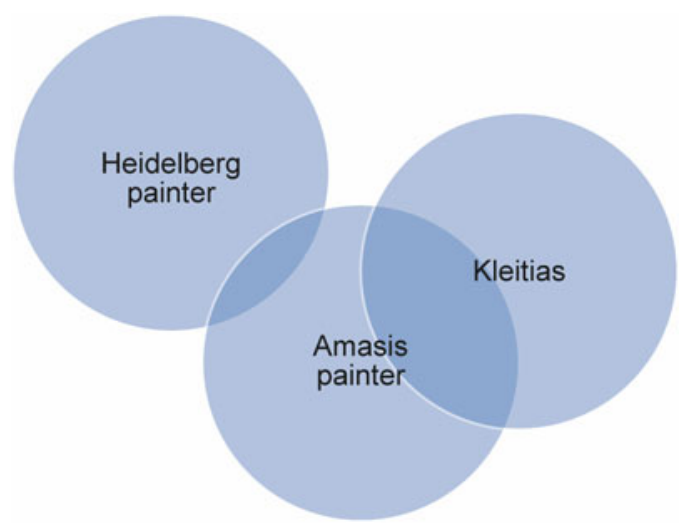

Figure I. Venn diagram showing the Amasis Painter's relationship to the Heidelberg Painter and Kleitias (after Beazley (I986) 52). Image prepared by Kirsty Harding. 'He has much in common with the Heidelberg Painter, surpassing him, however, in all respects; a good deal also of Kleitias, if not the finest part, has passed into him - lightness, elegance, and precise technique.'

\section{Personhood: the debate in anthropology and prehistory}

Though she did not coin the term, it was largely through Marilyn Strathern's ethnographic fieldwork in Melanesia (particularly New Guinea) that the term 'dividual' passed into anthropological discourse. Strathern conceived Melanesian persons - dividuals - as being radically different from Euro-American individuals. Whereas in our culture, clearly gendered persons are supposed to be the final locus of responsibility and identity, in Melanesia personhood is dispersed both among networks of other people (particularly kin) and among things (gifts, land). Melanesian persons are not so much discrete, bounded entities (individuals) as a locus of connexions of other people and things (dividuals) - assemblages of parts, if you will. As Strathern put it:

Far from being regarded as unique entities, Melanesian persons are as dividually as they are individually conceived. They contain a generalised sociality within. Indeed, persons are frequently constructed as the plural and composite side of the relationships that produced them. The singular person can be imagined as a social microcosm. ${ }^{22}$

These ideas were taken up in anthropology, particularly in the work of Alfred Gell, who graphically explained some of Strathern's ideas in the form of diagrams. ${ }^{23}$ For Strathern

\footnotetext{
22 Strathern (I988) I3.

23 Gell (I998b). For the application Gell's notion of agency in classical archaeology and art history see the papers in Osborne and Tanner (2007).
} 


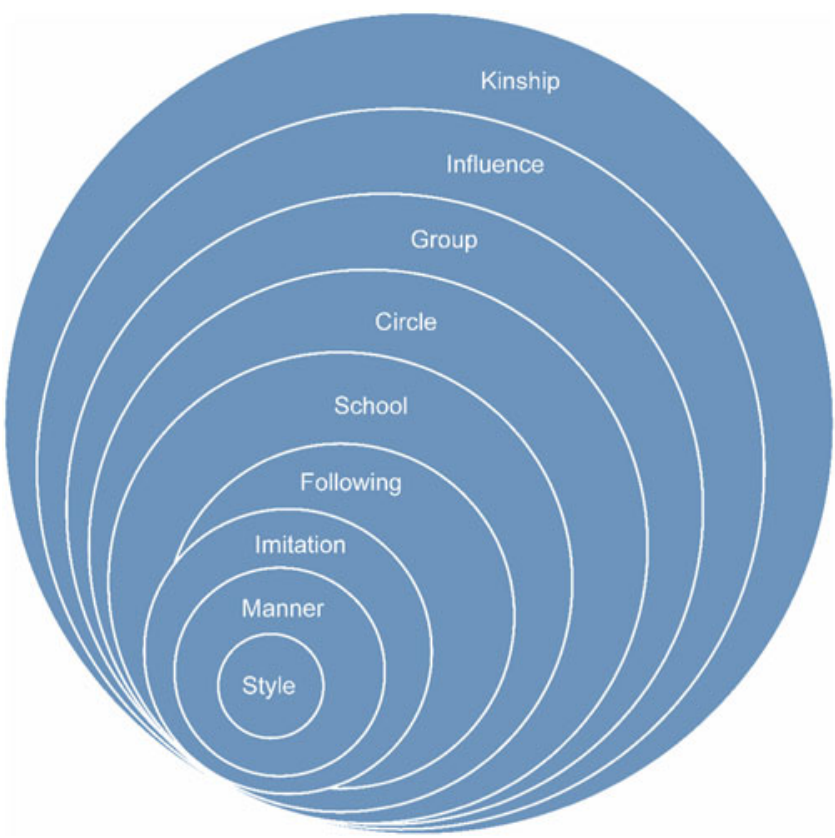

Figure 2. Venn diagram illustrating Beazley's use of the terms 'style', manner, kinship and so forth (after Beazley, ABV x). Image prepared by Kirsty Harding. 'My attributions have often been misquoted. I may perhaps be allowed to point out that I make a distinction between the vase by a painter and a vase in his manner; and that "manner", "imitation", "following", "school”, “circle”, "group”, “influence”, "kinship” are not, in my vocabulary, synonyms.'

as for Gell, where we might simply (in 'common sense' terms) see an exchange of pigs between two Melanesian men as being a straightforward transaction between two individuals, from a Melanesian perspective it is not only the pig that is being exchanged but a whole history of earlier exchanges, containing within it parts of the previous owners of the pigs. The pig then is never wholly given away (and is not simply a pig) but contains within it a whole universe of relationships. Gell built upon these ideas (and those of Nicholas Thomas), notably in his discussion of the distributed person in his 'Art and Agency'. ${ }^{24}$ Dividuals have distributed agency.

These ideas were then taken up enthusiastically by British prehistorians, notably Chris Fowler. Personhood was central to his interpretation of Neolithic of the Isle of Man. ${ }^{25}$ The notion of 'dividual' appealed to British prehistorians precisely because the concept

24 Gell (I998a) 96-I54 ('the distributed person'), building on Thomas (I991).

25 Fowler (2004). 
seemed to explain some of the curious recurrent patterns we find in the British and Irish Neolithic. Chief among these was the division of body parts in burials in collective tombs such as West Kennet Long Barrow. Here there was no attempt to maintain the integrity of persons buried within the chambers; rather disarticulated body parts (crania, long bones, ribs) had been sorted into different chambers by age and sex. ${ }^{26}$ British prehistorians have moreover resisted the inference that, with the coming of single grave inhumation at the end of the Neolithic, this form of personhood fundamentally changed. Beaker single inhumations in stone cists are no longer an index of the 'rise of the individual' in the Early Bronze Age. ${ }^{27}$

In sum then the way that the notion of personhood was received within British prehistory served to reinforce the established division of types of society. On the one hand were 'prehistoric and ethnographic' societies, inhabited by dividuals; on the other were literate 'historical and modern' societies, inhabited by individuals. Personhood thus served to reinforce the 'Great Divide' between European prehistory and the classical world. And the idea gained traction that, the further away from the West (either geographically or chronologically) you went, the greater the likelihood of encountering radically different persons - that is. dividuals. Table I sums up the picture.

Within anthropology however there were always scholars who thought this division a little too neat. The term 'dividual' was soon being qualified. Strathern had identified a 'partible' dividual in Melanesia; others were to discover 'permeable' ones in South India. ${ }^{28}$ An investigation of Inka personhood revealed that neither 'dividual' nor 'individual' quite summed up how Inka persons were understood within their own culture. $^{29}$ The most penetrating critique however came from within Melanesian scholarship. Edward LiPuma observed that if all 'Westerners' were entirely individuals, and all Melanesians dividuals, then mutual understanding - and so the kind of cultural translation that ethnography represents - would be impossible.

A Westerner can have access to Melanesian intentionality, and a Melanesian can have access to Western forms of intentionality because both operate in terms of dividual and individual aspects of personhood..$^{30}$

The divide (Table I) is then not so much ontological as ideological: Western political (democratic) and economic (capitalist) norms emphasise individualism; Maring (Melanesian) norms emphasise kinship, descent and dividualism. Within anthropology (and prehistory) the neat dichotomy represented by Table I has now completely broken down under the weight of explanation the concept has been required to bear. Dividual

\footnotetext{
26 Piggott (1962).

27 Brück (2004).

28 Busby (I997).

29 Wilkinson (2013).

30 LiPuma (1998) 62.
} 
Table I: The ontological divide between prehistory/ethnography and the study of historical societies.

\begin{tabular}{ll}
\hline Individual & \multicolumn{1}{c}{ Dividual } \\
\hline Euro-American and modern & Melanesian (and other) \\
Classical and historical & Prehistoric and traditional (i.e. ethnographic) \\
Rational & Irrational \\
Commodity & Gift \\
Locus of responsibility & Distributed responsibility \\
\hline
\end{tabular}

and individual are now seen as axes of personhood, rather than opposed essences. The latest article from Fowler makes this abundantly clear:

Personhood is not only relational and processual, it is multi-modal. More than one mode of relations, more than one mode of personhood, is likely to be present in any cultural context and one person may move between different modes of personhood as they engage in different activities. ${ }^{3 \mathrm{I}}$

Fowler's insight has direct bearing on how we should view the Amasis Painter (see below). What however neither prehistorians nor anthropologists can bring themselves to do is to acknowledge that this debate is not new. A 'personhood' debate had already taken place within classical studies several decades before it took off in anthropology.

\section{The personhood debate: classics and classical archaeology}

In 1949 E. R. Dodds, then Regius Professor of Greek at Oxford, gave the Sather lectures at Berkeley. He began with the subject of Agamemnon's apology - or rather non-apology - for his taking Briseis away from Achilles (the act that sets the whole plot of the Iliad - the 'wrath of Achilles' - going). ${ }^{32}$ Agamemnon (Hom. Il. I9.86-9) does not really accept responsibility

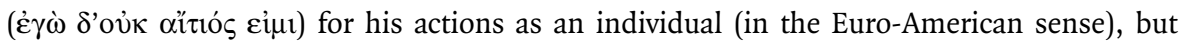
attributes his mistaken decision to a madness, an ö $\tau \eta$ sent down by Zeus. Now one might think here that 'Homer' is blackening Agamemnon's name - that he is a man and king uniquely incapable of accepting responsibility, as we understand the term. But Dodds shows that this is not the case - the point about this apology is not simply that it is made but also that it is accepted, and is couched in terms well understood by the moral community of Homer's heroes. Dodds then uses this example to build up a picture of the way that Homeric heroes talk about themselves - or rather don't. For they do not

3I Fowler (2016) 408 (emphasis original).

32 Dodds (I95I) I-27. 
talk about themselves as whole, bounded entities so much as about their parts (liver, heart and so forth). A good example of this façon de parler is Odysseus' reflection when, on his arrival on Ithaca, he is thinking back to his time in Polyphemus' cave: $\tau \dot{\varepsilon} \tau \lambda \alpha \theta \mathrm{r} \delta \dot{\eta}$,

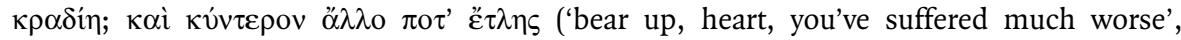
Hom. Od. 20.18).

Dodd's approach to Homeric heroes chimed in with that of another classical scholar writing at about the same time, Bruno Snell. Snell argued that early Greeks of the eight and seventh centuries BC did not have the concept of a body as a totality. It was rather an assemblage of parts, and one where the actual parts of the body (arms, legs) are no more essential what that body wears (helmets, spears, Dipylon shields). To support his point Snell drew attention to the way in which Geometric artists drew persons particularly warriors:

Dass der substantielle Körper des Menschen nicht als Einheit sondern als Vielheit begriffen wird, lehren uns auch die Menschendarstellungen der frühgriechischen Kunst. Den organisch einheitlichen Körper, der in der Spannung von Tragendem und Lastendem, im Gegensatz von Stand- und Spielbein und in der Abhängigkeit aller Teile von solchem Kontrapost sichtbar wird, stellt erst die klassische Kunst des 5. Jhdt. dar. Vorher ist der Körper wirklich nur aufgebaut durch die Addition einzelner Teile, wie das vor allem Gerhard Krahmer gezeigt hat. ${ }^{33}$

An example of such Geometric representations might be the early eighth-century Middle Geometric II krater 'from Attica' in New York (Figure 3). ${ }^{34}$ Here the persons - the warriorsand their shields are indistinguishable - shields are both shields and parts of bodies. The warrior is an assemblage of parts (helmet, shield, legs, pairs of javelin and spears).

Now of course these ideas never found wide acceptance within classical studies. Art historians have found fault with Snell, who they believe mistook a series of iconographic conventions for an underlying notion of 'the person'. Geometric artists may have been sophisticated in many ways but they were not interested in depicting people with any degree of anatomical accuracy. ${ }^{35}$ Other classical scholars were equally critical of Dodds, albeit for different reasons. The philosopher Bernard Williams argued against them both. For Williams these iconographic (and verbal) conceptions of the body (Snell) or ways of talking about personal responsibility (Dodds) did not imply a radical 'ontological' difference between our 'modern' selves and the ancient Greeks. ${ }^{36}$ While ancient Greek

33 Snell (1975) I7; cf. Snell (I953) (English translation of ist edn). Vernant (I989, II-I2) seems to follow Snell to some extent, without acknowledging his source, in his discussion of ancient conceptions of the body.

34 These early kraters are discussed in Whitley (I99I) I37-43 (see also ibid., Plate 27).

35 There is a kind of proxy debate about personhood in the 'Dipylon shield' controversy: are these shields real shields? Or are they meant to connote some notion of a generalised heroic past? For this see Snodgrass (1980); Boardman (1983); Hurwit (I985); Whitley (I99I) 45-53; on the continued relevance of Snell to this debate see Haug (2012) I9.

36 Williams (1993). Williams' interest of course was primarily in moral philosophy and in ethics, not in personhood as such. His arguments are principally directed against thinkers such as MacIntyre (1985), who 


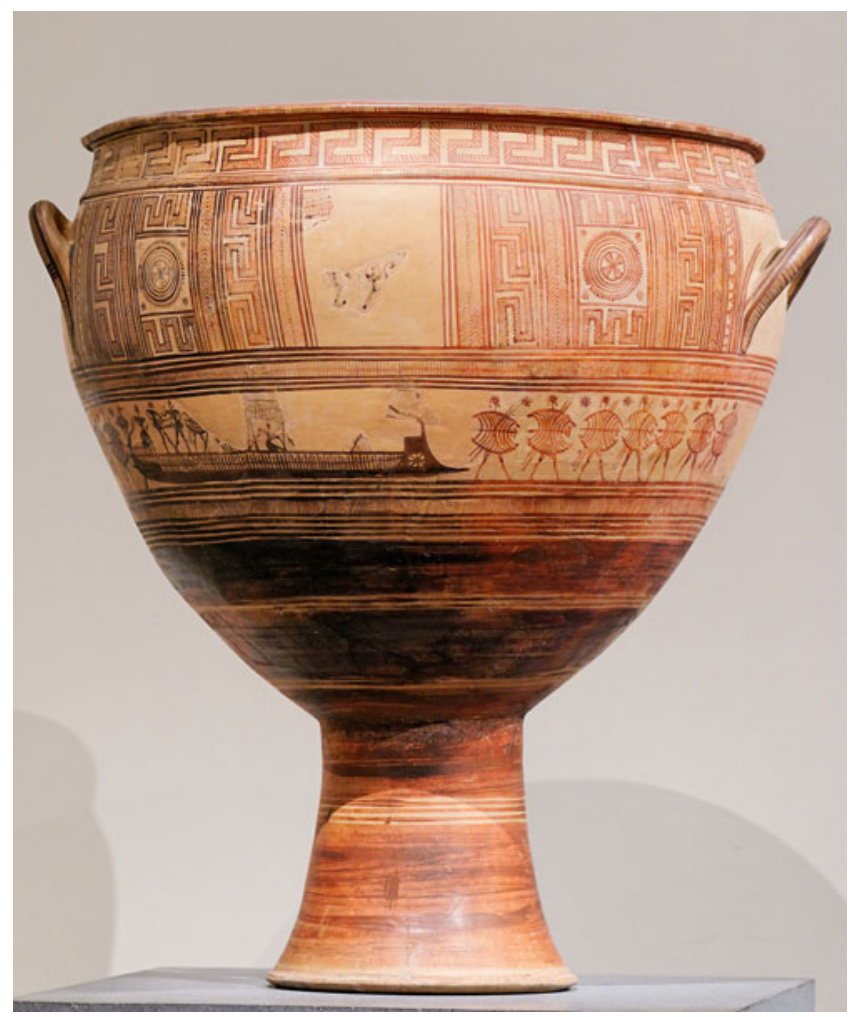

Figure 3. Middle Geometric in krater from Attica, now in New York (Metropolitan Museum of Art 34.II.2, Fletcher Fund 1934). Source Wikimedia Commons.

and modern senses of personhood might be different, and while ancient Greeks in general (and Homer's heroes in particular) might lack the words for 'moral' and 'responsibility', this does not imply that they could not act either morally or responsibly. Williams' critique of Snell is not so much of his notions of cultural difference between ourselves and archaic Greeks as of his 'progressivism' - that is, of Snell's moral teleology. ${ }^{37}$ Though he may not have intended it however, Williams' critique did lead to a neglect of both Dodd's and Snell's ideas. It came to be widely believed that current classical scholarship had transcended them..$^{38}$

argued that modernity is morally incoherent. This raises still broader issues (see Latour (I993)) which cannot be pursued here.

37 So one could read Williams (I993) as allowing for the possibility of 'moral' and 'responsible' dividuals, or allowing for the exploration of different kinds of responsibility within different 'ontologies' (sensu Descola (2013)). Vernant $(1983,343-74)$ is equally critical of Snell's teleology.

38 Finkelberg (2012) represents a recent consensus. 
The debate about personhood in anthropology and prehistory has however inadvertently revived interest in both Dodds and Snell and aligned their insights with those of anthropologists. Gell's notion of distributed personhood seems particularly appropriate for understanding Homeric exchange - an antique Cypriot amphoroid krater such as the one from the 'heröon' at Lefkandi Toumba may have had a similar history of entanglements as the famous silver krater Achilles sets up as a prize in the funeral games of Patroclus (Hom. Il. 23.740-9). ${ }^{39}$ Moreover, if there is something to Snell's interpretation of the 'Dipylon shield', then our relative ease in defining the 'Dipylon workshop' contrasts with the relative difficulty in defining the several hands that made up the 'artistic personality' of the Dipylon Master. ${ }^{40}$ In Sapirstein's terms recent scholarship has broken up the 'Dipylon Master' into a series of hands, the opposite of what people imagine the epistemological imperative of attribution to be.

Outside of the study of Geometric pottery however the personhood debate (either within classics, or prehistory, or anthropology) has had very little apparent effect on how the practice of attribution was understood within classical archaeology. Scholars who have participated in the debate about Beazley's legacy disagree about much: whether Beazley owed his method primarily to Giovanni Morelli ${ }^{41}$ or to Paul Hartwig; $;^{42}$ whether or not attribution can be extended into prehistory; ${ }^{43}$ and how 'fuzzy' the boundaries of artistic personalities might be. ${ }^{44}$ But all appear to agree that artistic personalities (at least those responsible for painting Athenian black- and red-figure vases) were - straightforwardly and unambiguously - individuals. That this assumption is no longer warranted is part of the central argument of this paper.

To re-assure some of my readers: I am not proposing to break down the corpus of vases attributed to the Amasis Painter into a group of 'hands' working in the 'Amasis workshop'. What follows is an iconographic study (where iconography is seen as an aspect of a painter's style), informed by these debates about both personhood and agency.

\section{Iconography and agency in the Amasis Painter I: eros and the hare}

Let us return to that distinctive sixth-century 'artistic personality', the Amasis Painter, and his iconography. I take it that a painter defined by style ('tricks of draughtsmanship') may

39 Cf. Hom. Od. 4. 6II-55, the krater given by Menelaus to Telemachus. All these are discussed in Grethlein (2008); Whitley (2013). For entangled objects see Thomas (I99I); for material entanglements Hodder (20II).

40 For the 'Dipylon Master' as an 'artistic personality' see Nottbohm (1943). For the 'hands' in the Dipylon workshop see Coldstream (1968) 29-32; Coulié (2015). It seems more and more likely that this workshop is a collection of hands, rather than one dominated by a single 'artistic personality'. Similar observations have been made about the Hirschfeld workshop, where an 'artistic personality' has become a brand (Vlachou (2015b)). For more on personhood and Geometric pottery see Whitley (2015) ro9-II.

4I As argued by Kurtz (1985). Beard (1991), Neer (1997) and Whitley (1997) largely accept Kurtz's view. For a comprehensive overview see Rouet (200I).

42 Williams (1996).

43 As argued by Morris (1993).

44 See Arrington (2017); Lynch (2017). 
also have a distinct iconography. If we can talk about the iconography of Titian, or Rembrandt, or El Greco, we can surely also talk about the iconography of Lydos, Exekias and the Amasis Painter. Let me reiterate the two main points of my argument. First, that Beazley's description of this painter allows an 'ontological' reading which sees him no less as dividual as individual (in Strathern's terms). In other words, the painter's personhood might be 'multi-modal' (to use Fowler's phrase). Second, that if we interpret this artistic personality in terms of 'anthropological' personhood we also have to imagine a more 'anthropological' understanding of his material entanglements, that is, the agency of the objects within the universe of the painter's iconography. Here I want to concentrate on two aspects of this: the hunting and giving of hares; and the handing over of shields (the so-called 'arming scenes').

Hares occur quite frequently on vases by the Amasis Painter. On an oenochoe in London a youth carries both a hare and a fox that he has hunted; ${ }^{45}$ on an amphora in Geneva a youth carries a (hunted) hare. ${ }^{46}$ But what have these hares been hunted for? A clue is provided on the paired images on either side of an unusually large drinking vessel, a cup-kotyle now in the Louvre: ${ }^{47}$ on one side a man with a beard offers a cock to a young girl; on the other another bearded male offers a hare to a beardless youth. That hares had erotic overtones within the ancient world is suggested by a rather strange, late passage in Philostratus the Elder (Imag. I.6.5): hares are the only animal that can be sacrificed to Aphrodite. That a hare is moreover a love gift appropriate for men (but not women) is confirmed by another image from an amphora in the Louvre where a younger man offers a hare to his older male lover. ${ }^{48}$ That hares could even be gifts for (male) gods is underscored by perhaps the most celebrated of these representations, that to be found on the neck amphora in the Cabinet des Médailles, where two maenads, one holding a hare by his ears, the other grasping a small deer, offer both creatures to their patron deity, Dionysus (Figure 4). ${ }^{49}$

Hares are wild creatures. To be given as gifts they first have to be hunted (Xen. Cyn. 2-8); in Greece then, as in Crete now, hares were hunted with dogs. Scenes of dogs chasing a hare occur on a number of Protocorinthian vases (such as the Chigi olpe, or the Macmillan aryballos). Such scenes are found on the lower registers of these vases beneath other scenes of fighting and hunting. ${ }^{50}$ Hare, deer and agrimi (the Cretan wild goat) are

45 London: BM B 52 from Rhodes; Karouzou (I956) 32 no. 30 and Plate 15; Beazley, ABV I53 no. 31.

46 Geneva: I.4; Karouzou (I956) 30 no. 6 and Plates 4 and 5; Beazley, ABV I50 no. 8.

47 Louvre: A 479 from Rhodes (Camirus); Karouzou (I956) 37 no. 7I and Plates I2.2, I3 and I4; Beazley, ABV I56 no. 8o. Beazley rather mysteriously calls the hare a 'panther cub', which it is not. All these erotic scenes are discussed by Schnapp (1997) 239-4I.

48 Amphora type B, Louvre F26; Karouzou (1956) 30 no. I7; Beazley, ABV i50 no. 5.

49 Paris, Cabinet des Médailles 222 (from Vulci); Karouzou (I956) 3I no. 22 (see also discussion pp. I8-I9) and Plates 3I and 32; Beazley, ABV I52 no. 25, (I986) 52-3 and Plate 5I. Beazley calls the hare (and the deer) 'pet animals'; that maenads would have pets might surprise anyone who knows anything of Euripides' Bacchae. This vessel has many

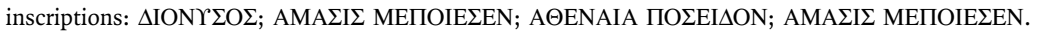

50 Chigi vase: Hurwit (2002); Macmillan aryballos and other vases: Amyx (I988) 368-72, Plate II. Similar scenes are to be found on a number of Attic black-figure vases that predate the Amasis Painter; see Schnapp (I997) 2I2-I8. On 'performative masculinity' on Protocorinthian perfume flasks see Shanks (1999) 73-168. 


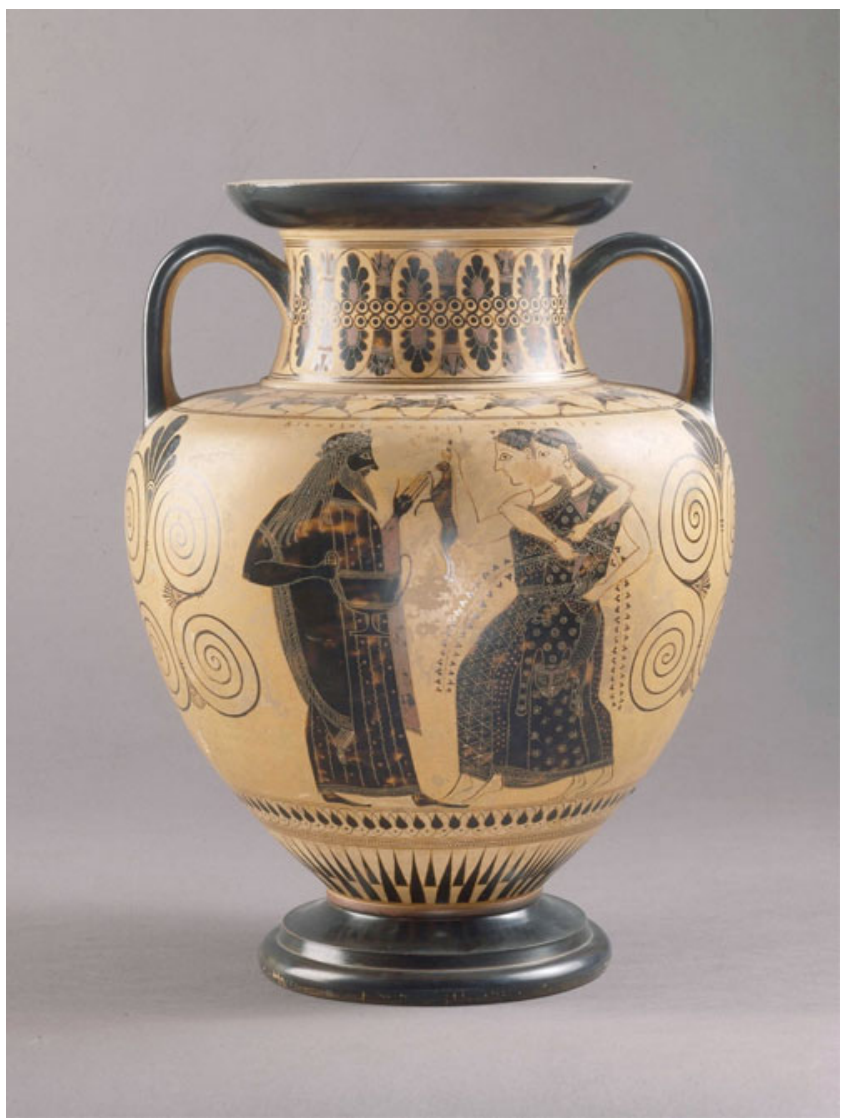

Figure 4. Paris, Cabinet des Médailles 222 (from Vulci); Karouzou (I956) 3I no. 22; Beazley, ABV I52 no. 25, (I986) 52-3. Two maenads offer Dionysus a hare and a deer. Image courtesy Cabinet des Médailles, Paris.

represented on Archaic bronze plaques from the sanctuary of Hermes and Aphrodite at Kato Symi in Crete. On these plaques young men exchange love gifts, frequently of wild animals one of them has hunted. The excavator Angeliki Lebessi interprets these images as part of a much longer initiation process by which young men became citizens of a Cretan polis through institutions such as the andreion..$^{{ }^{\mathrm{I}}}$ The gesture on one plaque (A.Io) is almost

5I Lebessi (1985) 26 no. Aio, Plates 6 and 48. Lebessi goes on (ibid., i88-98) to discuss how these plaques relate to the rituals associated with the formation of the Cretan 'troops' based on the well-known passage in Strabo (Io.4.20-I), who in turn paraphrases Ephoros (FGrH 10.I49). It is not necessary (contra Koehl (I986)) to infer that such rituals have 'Minoan roots'; see Whitley and Madgwick (2018). 
identical to those found on the Louvre amphora and the one in the Cabinet des Médailles (Figure 4). Recent investigation of the civic centres of Cretan poleis (at Azoria, Dreros and Praisos) has revealed an unusually high proportion of hare bones, wild animals consumed in a communal civic and ritual setting. ${ }^{52}$ In Crete then hares were much more than simply food - that is sustenance; their procurement and consumption were part of an exchange between men that strengthened civic bonds.

Hares are thus not only associated with homoerotic love but also with performative masculinity (since it takes both skill and effort to catch one). They are therefore invested with a particular kind of agency. Here we return to the link between personhood and agency advocated by Gell. Just as in the example of Melanesian exchange the pig being exchanged isn't just a pig but rather the nexus in a whole set of social relationships, so the hare found in these images is not just a hare but is entangled within a whole set of distinct relationships: in Athens the formation of bonds between erastēs and eromenos; and in Crete the formation of new generations of citizens within political communities. These apparently simple gestures contain multitudes.

\section{Iconography and agency in the Amasis Painter II: heroes and shields}

A similar point can be made with the Amasis Painter's use of shields. As Boardman notes, this painter is very keen on shields, depicting both elaborately heroic Dipylon/Boeotian examples and more standard round hoplite shields. ${ }^{53}$ The best known are two arming scenes, one (on an amphora in Berlin) apparently shows Thetis giving a Boeotian shield to Achilles, ${ }^{54}$ another, a neck amphora from Orvieto in Boston, shows Thetis giving Achilles a round hoplite shield ${ }^{55}$ (Figure 5; Figure 6). Beazley is, interestingly, ambivalent in his interpretation of these depictions - while he is sure that the image depicted on the neck amphora from Orvieto represents the original gift of arms to Achilles (Figure 5), he is not so sure about the amphora once in Berlin. ${ }^{56} \mathrm{I}$ am convinced however that both represent the same event - the original gift of divine arms made by Hephaistos and given by Thetis to her son Achilles at Phthia in Thessaly, a tale that later came to form part of the Kypria (a part of the epic cycle that precedes the Iliad). My reasons are several; they relate both to the agency of the shield and the iconography of the scene.

First agency: of all the artefacts known in archaic and early classical Greece one could argue that it is shields that are invested with most agency. 'Come back with your shield

52 Discussed in Whitley and Madgwick (2018).

53 Boardman (I975) 54-6; on Archaic shields generally see Snodgrass (I964) 58-68.

54 Amphora type A: Berlin 3210; Karouzou (I956) 29 no. 2 and Plates 25 and 26 (also discussed pp. I4-16 and note 3); Beazley, ABV I5I no. 2I. This amphora is now lost.

55 Neck amphora: Boston or.8027 (from Orvieto); Karouzou (I956) 31 no. 23 (also I9-20) and Plates 32, 34 and 35.1 and 2; Beazley, ABV I52 no. 27.

56 Beazley (I986) 53-5. 


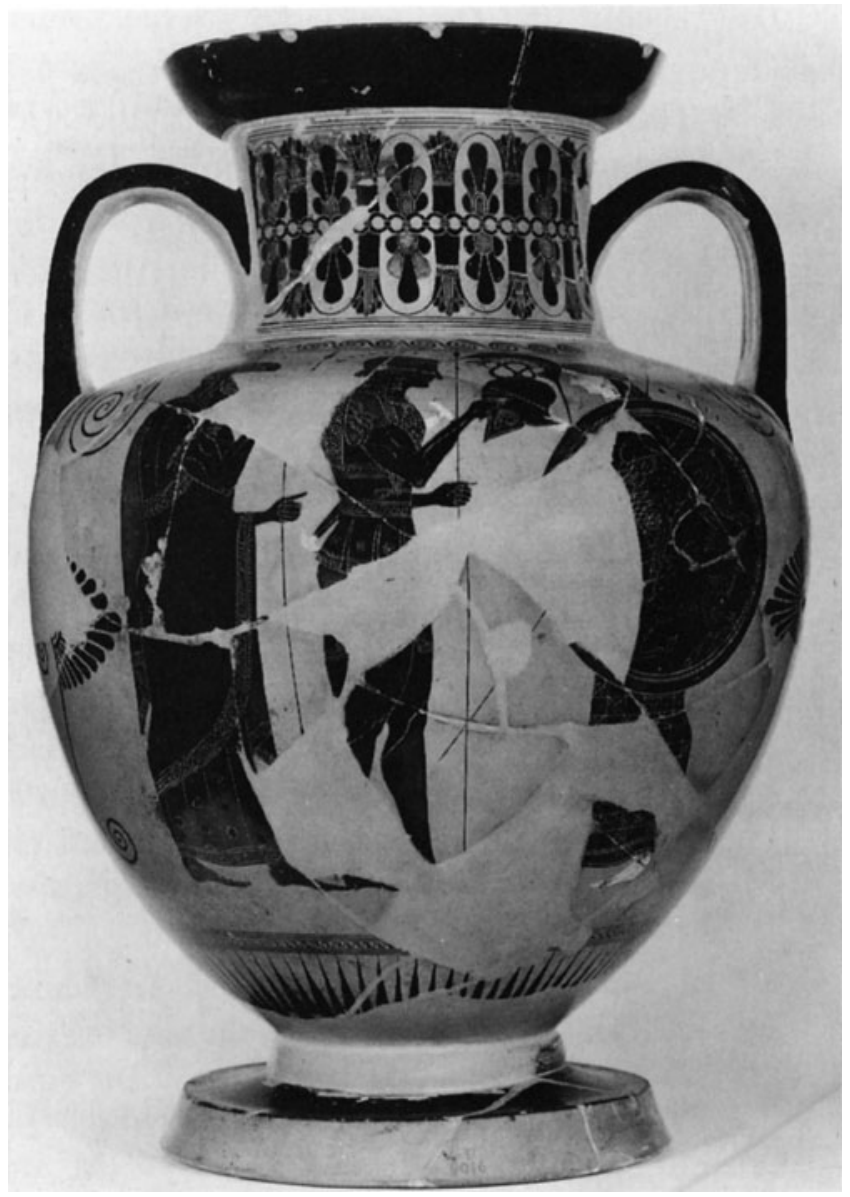

Figure 5. Neck amphora: Boston or.8027 (from Orvieto); Karouzou (I956) 31 no. 23 (also I920) and Plates 32, 34 and 35.I and 2; Beazley, ABV 152 no. 27. Thetis gives Achilles his arms. Image courtesy Museum of Fine Arts, Boston.

or on it', say Spartan mothers to their sons; ${ }^{57}$ shields are, after helmets, the preferred form of dedicatory offering commemorating military victories. The Phokians, who defeated the invading Thessalians at some point in the late sixth century BC, dedicated 2,000 of their

57 This tradition is, of course, very late; it is only recorded in Ps.-Plutarch, Moralia (Apophthegmata Laconica) 24I. F. no. I6. I would argue that it is however implied by Thucydides' account (especially $4.36 .3 ; 4.37 .2-38.1$; 4.40.I) of the Sphakteria episode and his incredulity that Spartans had actually given up their arms (and in particular their shields). 


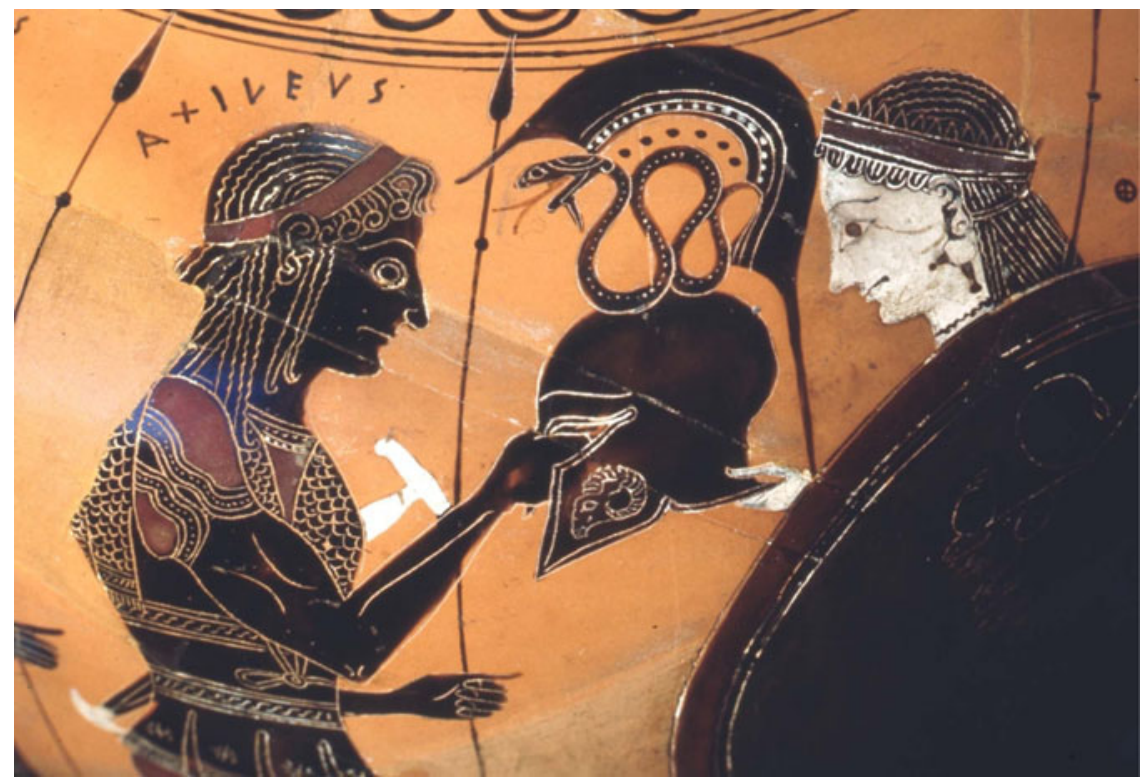

Figure 6. Detail of image in Figure 5 (Boston or.8027), showing crest of helmet and ram's head cheek piece. Image courtesy Museum of Fine Arts, Boston.

captured shields at sanctuary of Apollo at Abai (Hdt. 8.27; Paus. I0.I.3-9); the Athenians pointedly displayed the shields they had captured at Pylos from the Spartans prominently in the Painted Stoa..$^{8}$ Shields are also depicted within shields - as on a number of Argive shield bands dedicated at Olympia (Figure 7). ${ }^{59}$ And of all the shields we know of from literature, the one that Thetis gives to Achilles (the original arms) at Phthia in Thessaly is the one invested with most agency. The shield is originally a divine gift; then Achilles lends it to Patroclus; then Hector seizes it from Patroclus' dead body; and then finally (after obtaining his second suit of armour) Achilles recovers the original shield by killing Hector (Hom. Il. 17.194-7, 18.84-5, 22.322-3). From one point of view therefore, this armour, this shield can be viewed as one of the major dramatis personae of the Iliad itself. ${ }^{60}$

Is then the shield that the Amasis Painter depicts in Figure 5 this 'original' shield? Discussions of the iconography of arming scenes have now become a dense thicket of scholarly controversy. In his interpretation of the 'arming' scenes painted by the Amasis

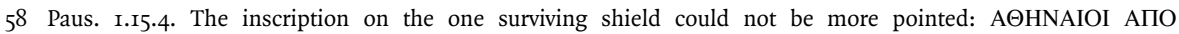
$\Lambda \mathrm{AKE} \Delta \mathrm{AIM}[\mathrm{ON}] \mathrm{ION} \mathrm{EK}[\Pi \Upsilon] \Lambda \mathrm{O}$ 'The Athenians [took these] from the Lacedaemonians from Pylos'; on the discovery of this shield, see Shear (1937); on the agency of its inscription, Whitley (2006) 229-32.

6o Grethlein (2008); Whitley (2013) 399. 


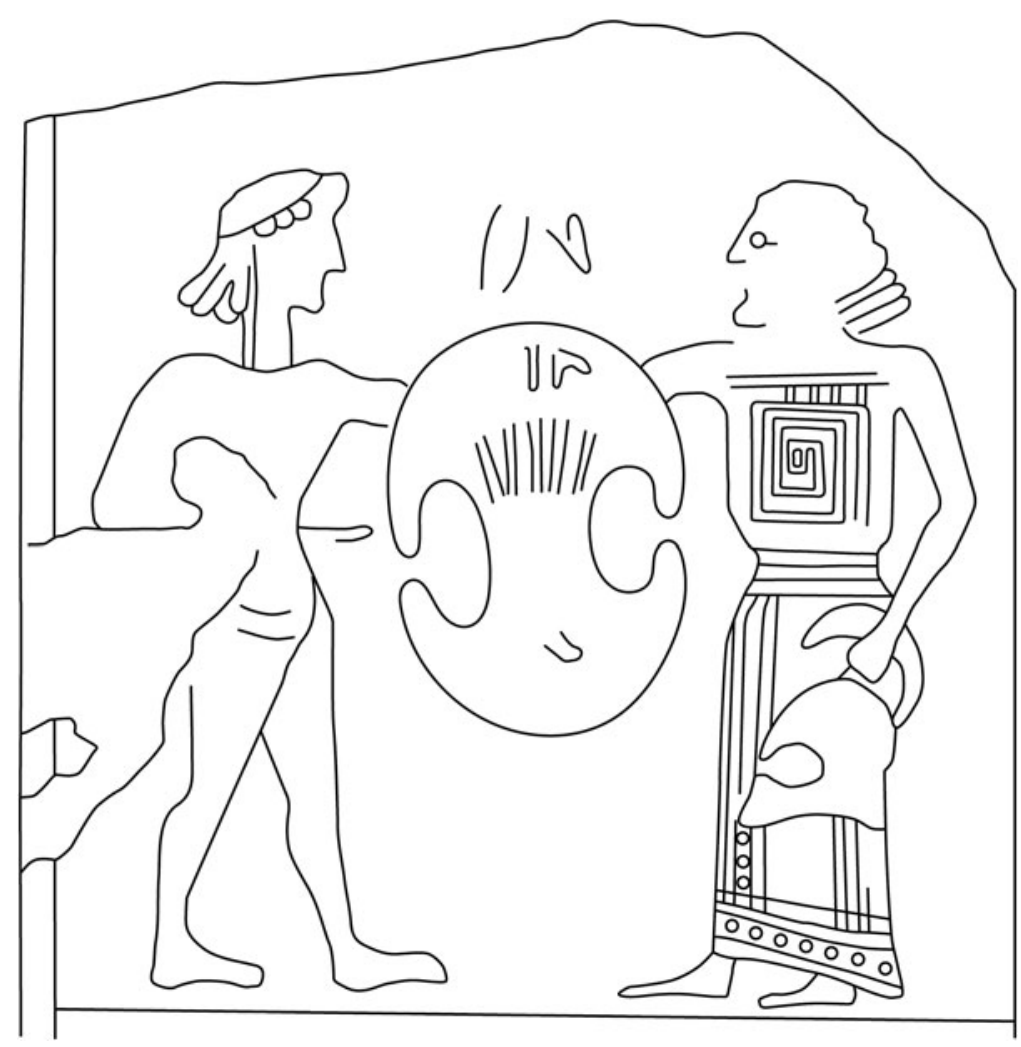

Figure 7. Bol (1989) 67 and 153 no. cxiv H.40 no. $\gamma$ (Olympia inventory B8150). This shows Thetis giving Achilles a Boeotian shield. Image redrawn by Kirsty Harding.

Painter Beazley was following Friis Johansen's comprehensive study. ${ }^{6 r}$ Beazley neatly summarises his argument:

Johansen shews that the arms in the early vases (not the late archaic) are not the 'replacement' set of the $18^{\text {th }}$ book, but the original set, Hephaistos-made like the other, brought the hero by Thetis and her sisters before he left Phthia for Troy. ${ }^{6}$

A point in favour of this interpretation is a scene on a plate by Lydos, which shows Peleus, Achilles, Thetis and Neoptolemus all present in the 'arming of Achilles'. This cannot be the scene recounted in the Iliad - 'that the presence of Neoptolemos is a

$6 \mathrm{I}$ Friis Johansen ( $\mathrm{I}_{6} 67$ ) 92-II3, original Danish version reviewed by Beazley (I934).

62 Beazley (1934) 84-5. 
proleptic sin against the legendary tradition, did presumably not worry the artist'. ${ }^{63}$ Friis Johansen's arguments were elaborated by Dietrich von Bothmer. Von Bothmer developed his interpretation through a close study of a vase by the Camtar Painter now in Boston (Figure 8). ${ }^{64}$ This vase seems to have established the standard iconography for arming scenes. ${ }^{6}$ Here Achilles receives a particularly elaborate Boeotian shield from Thetis, and the rest of his divine armour from a succession of named (and inscribed) nymphs: Kymatothea (for the cuirass); Neoptolome (for the greaves); and Panope (for the Corinthian helm). ${ }^{66}$ This interpretation has been criticised by both Lowenstam and Giuliani. ${ }^{67}$ Lowenstam provides a point-for-point rebuttal of Friis Johansen's (and von Bothmer's) original argument to the effect that these scenes must reflect the first arming at Phthia rather than the second before Troy. Lowenstam's view is that no particular mythological event - neither the first arming, nor the one in book is of the Iliad - can positively be identified on any of these generic arming scenes. Giuliani goes further, and doubts that there even was a widely known tale of an original gift of arms by Thetis to Achilles in Phthia. ${ }^{68}$ The only gift of divine armour from Thetis to Achilles was the one that takes place in the Iliad (I9.I2-I3).

Giuliani's interpretation is, in my view, not sustainable. First, if the only identifiable arming scene found on the iconography of archaic vases is the one that stems from this brief passage in the Iliad, then the scenes themselves are unaccountably rich in the kind of detail that points in a very different direction. In this passage in the Iliad (19.12-I3) the only spectators present (apart from Thetis and Achilles) are the Myrmidons. The Nereids (Il. 18.39-49) who had accompanied Thetis when she visited the grieving Achilles are not mentioned; nor is their presence at all implied. Second, the 'shield of Achilles' (Il. I8.478-608) must have been a round shield, and not the Boeotian shield depicted in Figure 8. The inscriptions on the vase by the Camtar Painter rule out any of the other three arming scenes in the Iliad - those of Paris, Agamemnon and Patroclus. ${ }^{69}$ Indeed, what Giuliani's cursory exclusion of the Phthia hypothesis ignores ${ }^{70}$ is the way in which the agency of objects, both within the Iliad itself and within the iconography of heroic scenes on sixth-century Athenian vases, look beyond the immediate episode depicted and reference earlier and later episodes in the Trojan War Cycle. This applies to the spear taken from the original 'arms of Achilles' that Patroclus cannot wield, a spear made of

63 Friis Johansen (I967) II3. The vase (Athens NM 507; Beazley, ABV II2 no. 56) is illustrated ibid., Io9 Figure 35.

64 Boston 2I.2I; Beazley, ABV 84 no. 3; Friis Johansen (I967) 93-6 Figures 23-5.

65 See discussion by von Bothmer (1949); Beazley (1986) 53-5; Lissarrague (1990) 43-7; Giuliani (2013) I07 Figure 22.

66 Kymothoe and Panope (but not Neoptoleme) occur in the list of thirty-three Nereids who accompany Thetis when she visits the grieving Achilles (Hom. Il. 18. 39-49). No Nereids however seem to be present when Thetis hands over the second set of arms (Hom. Il. I9.I2-I3). See discussion by von Bothmer (I949).

67 Lowenstam (1993); Giuliani (2013) 105-10.

68 Giuliani (2013) 287 n. 70.

69 Il. 3.328-38 (Paris); II.15-55 (Agamemnon); I6.130-54 (Patroclus). As Armstrong (I958) argues, these scenes are successively more elaborate and refer back (and forward) to each other.

70 Quite apart, that is, from any discussion of the plate by Lydos (see above). 


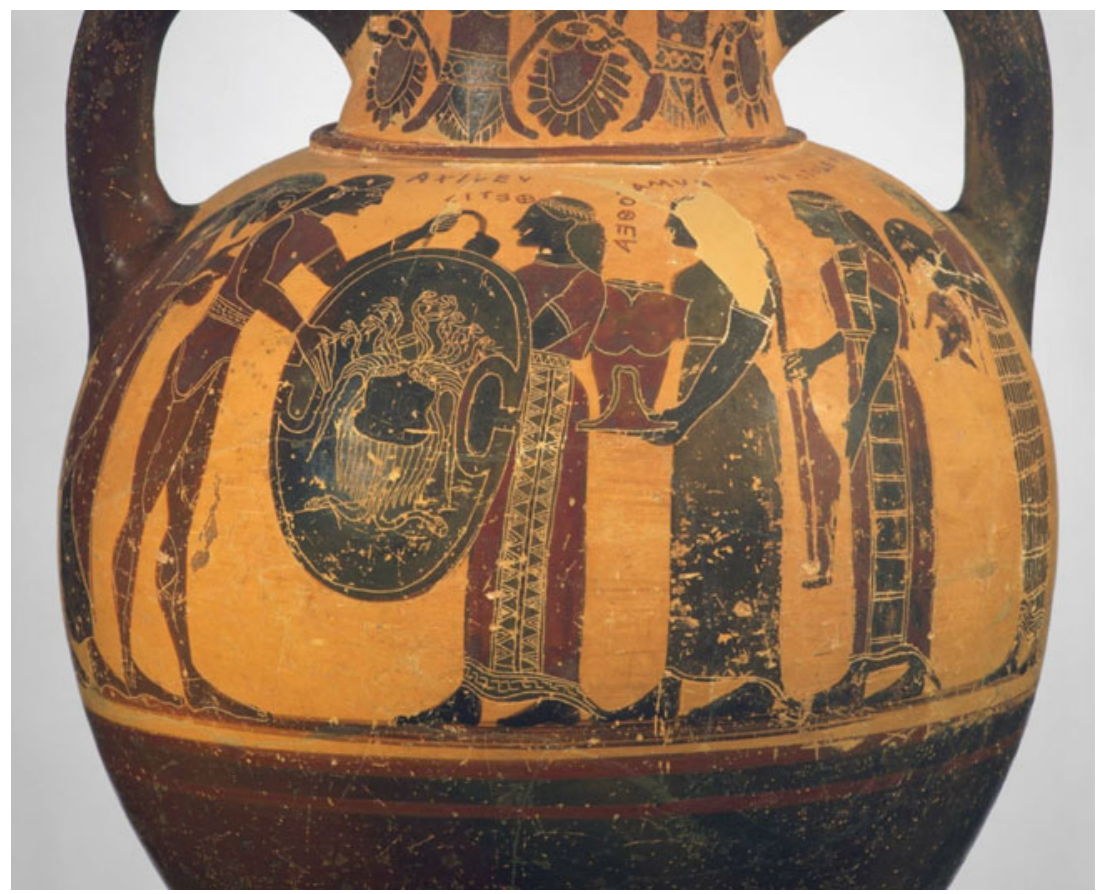

Figure 8. Amphora by the Camtar Painter, in Boston (Museum of Fine Arts); Boston 2I.2I; Beazley, ABV 84 no. 3. Image courtesy Museum of Fine Arts, Boston.

ash from Mt Pelion ( $\Pi \eta \lambda i \alpha ́ \delta \alpha \mu \varepsilon \lambda i \eta \eta v)$, which Cheiron gave to Peleus and then Peleus to Achilles (Il. I6.I40-4) and whose size and weight make it a particularly deadly instrument

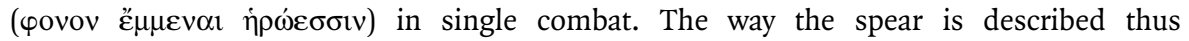
foreshadows Achilles slaying of Hector. These original weapons and arms of Achilles act as major dramatis personae within the Iliad itself (see above). Their origin and their agency are thus key to the Cycle as a whole. It is then not surprising that the original gift of arms by Thetis to Achilles is something that very much preoccupied early vase painters interested not in the Iliad in particular but the Trojan War Cycle in general. ${ }^{7 \mathrm{~T}}$

In brief, sixth-century vase painting is full of Friis Johansen's 'proleptic sins'. The problem of how Bild relates to Lied is not 'how do painters evoke Homer'; Homer's Lied was not at this point some fixed text but rather a corpus of oral tale cycles which were only taking definitive shape around the middle of the sixth century $\mathrm{BC}$ (that is, the time

7 I Snodgrass (1998), esp. I44-5. Snodgrass, unlike Giuliani, also considers the (highly ambiguous) evidence for the 'Chest of Kypselos' on this point (Snodgrass (2006) 422-42). I myself do not find the alternative explanation for the apparent absence of specific imagery relating to the Iliad in particular (rather than the Trojan War Cycle in general) put forward by Osborne (2018) at all convincing. 
of the Amasis Painter). ${ }^{72}$ The problem vase painters faced was how to make a scene look, like the 'objects with agency' within the Iliad, both back to what had gone before and forward to how the story ends. ${ }^{73}$

Giuliani's argument of course is that Bild does not depend directly on Lied. Artists faced different problems from poets, and in the move from Geometric to black-figure they began with the generic (an arming scene) and added features (including inscriptions) that lead to the particular (the arming of Achilles). In Giuliani's evolutionary account, Figure 7 precedes Figure 8; the first is a generic scene, the second the 'arming of Achilles'. But if this is so then almost all the 'myth' scenes we find on Archaic metalwork (including all of those found on so-called 'Argive' shields) must be generic - both Bol and Kunze must have been wrong in all of their interpretations of the scenes that appear on the interior bands of these round hoplite shields. ${ }^{74}$ The Argive depictions within shields are, if anything, later in date than the Camtar Painter (they are more or less contemporary with the Amasis Painter). In this light is it not more likely that the images on the shields are derived from more complex images on vases, rather than the other way around?

If so, we should reverse Giuliani's interpretation. It is the developed iconography on Figure 8 which is 'abbreviated' on the image of the 'shield within a shield' on the Argive shield band (Figure 7), and it is this 'abbreviated' iconography which the Amasis Painter would be working with (or against) on other scenes involving the 'arms of Achilles'. On another amphora in Boston from Orvieto, two warriors (Achilles and Hector) are seen battling, one holding a Boeotian shield with a scene of two rams butting each other; ${ }^{75}$ a third in New York ${ }^{76}$ shows two arming scenes. On one side of the vase in New York a man gives a warrior (Achilles? - not named) who is putting on his greaves a metal ring, while another holds his (round, hoplite) shield; on the other a man again puts on his greaves, a female figure (Thetis?) holds an aryballos, while a man behind her holds another (round, hoplite) shield. In all these scenes the Amasis Painter is playing with the ancient (and modern) viewers' expectations of what is heroic (round shield or Boeotian shield), underpinned by a wide understanding of the continued agency of the 'arms of Achilles'. ${ }^{77}$

72

Burkert (I987); Nagy (1990), (I997); for further implications see Burgess (2009).

See the classic account of Snodgrass (2006) 38I-406.

Bol (1989) 63-76; Kunze (I950) 139-73. See discussion by Giuliani (2013) I05 Figure 2I.

Neck amphora: Boston or.8026 from Orvieto; Karouzou (I956) 32 no. 24 (discussed 20-I) and Plates 35.3, 36 and 37; Beazley, ABV I52 no. 26. Signed twice.

Amphora type B: New York 06.ro2r.69; Karouzou I956, 29 no. 4 \& plates I and 2.I; Beazley ABV I50 no. 2.

This of course raises the question of who constituted the original ancient audience - the ancient viewers - of these vases. I cannot agree here with the view, widely held (e.g. Neer (2002), criticised in Whitley (2018) 63-70), that this ancient audience was primarily an Athenian one. Twenty-two of the vases listed in Beazley, ABV I50-8 come from Etruscan contexts, fifteen from elsewhere in the Mediterranean, and only eleven from Attica. Prominent among the proveniences of those larger vases (such as amphoras) with the more elaborate 'mythological' scenes are the sites of Orvieto and Vulci. The distribution of the Amasis Painter's wares is thus very similar to that of the Berlin Painter's (Saunders (2017)). 
It is then the agency of the shield (the original divine armour) that is reflected in its iconography (rather than the other way around). Let us return to the Boston vase in Figure 5, and look again at the agency and iconography of the objects within it. This ensemble of images comprises the following: a curious blazon on the centre of the round shield that Thetis gives to Achilles (and which cannot correspond to the shield described in book 18 of the Iliad); the odd 'serpent support' for the crest of the helm; and the image of the ram's head on the cheek piece of the same helm (Figure 5). All these elements look forward to the full 'object biography' of these arms, arms which act as agents, as dramatis personae within the wider narrative of the Trojan War Cycle. These details then are supplied in the service of a prospective narrative - hints of what is to come. Once we take all this into account we must recognise that the Amasis Painter, in his serial committal of multiple narrative 'proleptic sins', is fully the equal of his great contemporary, Exekias.

\section{A provisional conclusion}

This article began with a consideration of personal style. Style has often been taken to betray the presence of an individual - not merely an identifiable person, but also someone whose personality infuses his (or her) work. It went on to consider how the uncertainties in defining 'artistic personalities' from a mass of hands raises questions which are as much ontological as epistemological. If personal style is considered 'ontologically' that in turn raises issues of personhood, and this paper considers how parallel debates about personhood have developed, first in classics and then in anthropology (and prehistory). It suggested that we are not really forced to choose whether ancient Greeks (and ancient Greek vase painters) were more dividual than individual, since personhood could be 'multi-modal'. While the practice of signing works is (rightly) seen as an indication of ancient Greek 'individualism', ${ }^{78}$ the entanglements between persons and things evident equally in Homeric narratives and in archaic iconography are more consistent with a notion of the 'dividual' or 'distributed person' (in Gell's sense).

The Amasis Painter is central to all these debates. His visual narratives are caught up with the wider agency of both persons and things. We could speak of the Trojan War Cycle as an entangled narrative, ${ }^{79}$ played out in poetry and the visual arts, that links people and objects together. Just as agency is invested in objects, so personhood is entangled with things. In this sense both personhood and agency are not only 'multimodal' (in Fowler's terms) but also 'polythetic' (in David Clarke's). This brings us back to the wider definitions of style mentioned at the beginning of this paper. Style also operates at a macro-level and has traditionally been linked to ethnicity - La Tène style

78 As in Hurwit (2015), esp. 3-30 and $147-56$.

79 In view of the shift in scholarly consensus that Nagy (1990; 1997) represents it seems best to talk about the Trojan War Cycle (understood as a loose collection of tales, which vary according to oral performance) rather than 'Homer' (understood as the sole author of two fixed and definitive texts). 


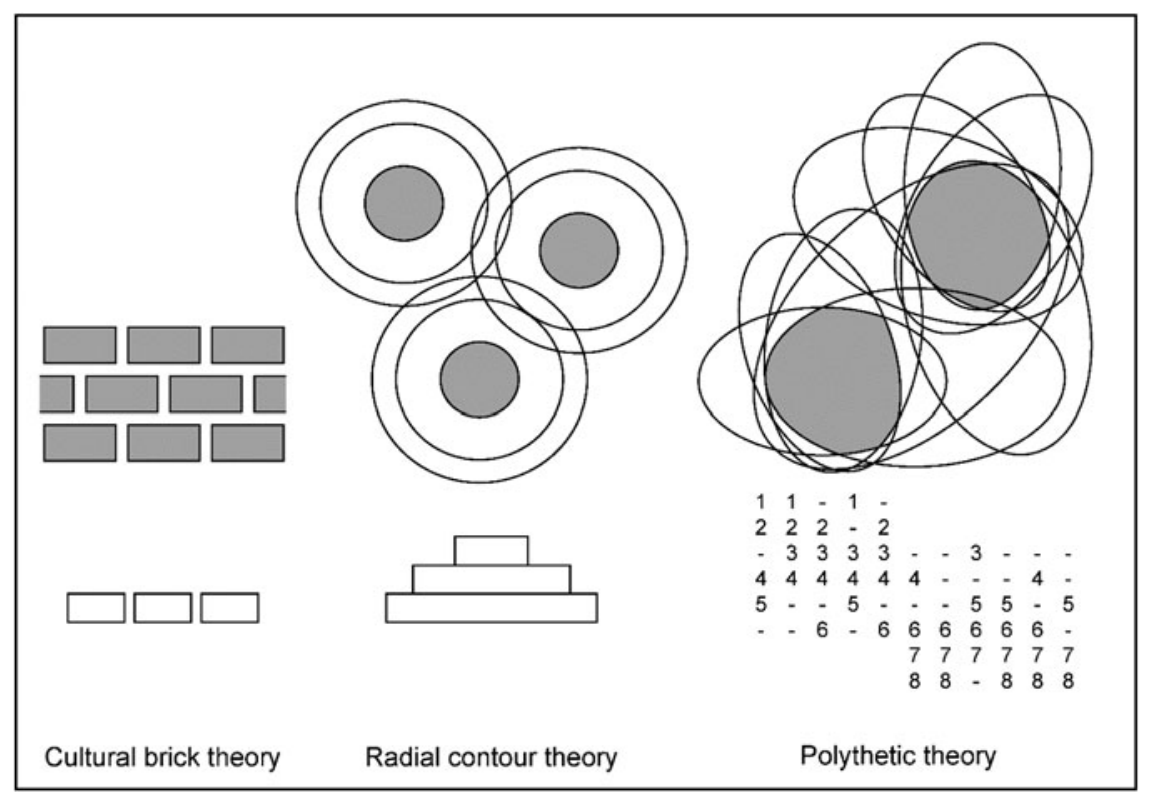

Figure 9. The 'culture brick', 'radial contour' and 'polythetic set' models of archaeological cultures (prepared by K. Harding, after Clarke (I978) 264 Figure 67).

with the Celts, and Classical style with the Greeks. But this notion of style also depends on a more general theory of - or assumptions about - culture in general. Insofar as style, at a macro-scale, is an integral part of culture (and culture too is, in part, a particular configuration of material entanglements), it too is polythetic. As David Clarke saw (with great perspicacity) fifty years ago, ${ }^{80}$ culture is polythetic all the way down (Figure 9 ).

\section{Works cited}

$\mathrm{ABV}=$ Beazley $(1956)$

Amyx, D. A. (I988) Corinthian vase painting of the Archaic period, 3 vols., Berkeley and Los Angeles.

Armstrong, J. I. (1958) 'The arming motif in the Iliad', AJPh 79, 337-54.

Arrington, N. (2017) 'Connoisseurship, vases, and Greek art and archaeology', in. J. M. Padgett (ed.),

The Berlin Painter and his world: Athenian vase painting in the early fifth century BC, New Haven and London, 2I-39.

Beard, M. (I99I) 'Adopting an approach II', in T. Rasmussen and N. Spivey (eds.), Looking at Greek vases, Cambridge, I2-35.

Beazley, J. D. (I9II) 'The Master of the Berlin amphora', JHS 3I, 276-95.

(I922) 'Citharoedus', JHS 42, 70-98.

8o Clarke (1978) 245-362 (ist edn ig68). 
(1932) 'Little Master cups', JHS 52, I67-204.

(1934) Review of 'Iliaden I tidlig graesk Kunst' by K. Friis Johansen, JHS 54, 84-5.

(1956) Athenian black figure vase painters, Oxford. (= ABV)

(I986) The development of Attic black-figure, rev. edn by D. von Bothmer and M. B. Moore, Berkeley and Los Angeles.

Boardman, J. (1975) Athenian black figure vases, London.

(1983) 'Symbol and story in Geometric art', in W. G. Moon (ed.), Ancient Greek art and iconography, Madison, $15-36$.

(I987) 'Amasis: the implications of his name', in True (I987) I4I-52.

Bol, P. C. (I989) Argivische Schilde, Olympische Forschungen xvII, Berlin and New York.

Brück, J. (2004) 'Material metaphors: the relational construction of identity in Early Bronze Age burials in Ireland and Britain', Journal of Social Archaeology 4, 307-33.

Burgess, J. S. (2009) The death and afterlife of Achilles, Baltimore.

Burkert, W. (1987) 'The making of Homer in the sixth century BC: rhapsodes versus Stesichoros', in True (I987) 43-62.

Busby, C. (1997) 'Permeable and partible persons: a comparative analysis of gender and body in South India and Melanesia', Journal of the Royal Anthropological Institute 3, 26I-78.

Carpenter, T. H. (I986) Dionysian imagery in Archaic Greek art: its development in black-figure vase painting, Oxford.

Clarke, D. L. (1978) Analytical archaeology, 2nd edn, London.

Coldstream, J. N. (ig68) Greek Geometric pottery: a survey of ten local styles and their chronology, London.

Cook, R. M. (1972) Greek painted pottery, 2nd edn, London.

Coulié, A. (2015) 'L'atelier du Dipylon: style, typologie et chronologie relative', in Vlachou (2015a) 37-47.

Descola, P. (2013) Beyond nature and culture, tr. J. Lloyd, Chicago and London.

Dodds, E. R. (I95I) The Greeks and the irrational, Sather Classical Lectures 25, Berkeley and Los Angeles.

Dunbabin, T. J. and M. Robertson (I953) 'Some Protocorinthian vase painters', ABSA 48, I72-8I.

Finkelberg, M. (2012) 'E.R. Dodds and the irrational: Agamemnon's apology re-visited', SCI 3I, IOI-8.

Fowler, C. (2004) The archaeology of personhood: an anthropological approach, London and New York.

(2016) 'Relational personhood revisited', CArchJ 26, 397-412.

Friis Johansen, K. (1967) The Iliad in early Greek art, tr. L. Christensen, Copenhagen.

Gell, A. (I998a). Art and agency: an anthropological theory, Oxford.

(1998b) 'Strathernograms, or the semiotics of mixed metaphors', in A. Gell, The art of anthropology: essays and diagrams, London, 29-75.

Giuliani, L. (2013) Image and myth: a history of pictorial narration in Greek art, tr. J. O’Donnell, Chicago.

Grethlein, J. (2008) 'Memory and material objects in the Iliad and the Odyssey', JHS I28, 27-5I.

Haug, A. (2012) Die Entdeckung des Körpers: Körper- und Rollenbbilder im Athen des 8. und 7. Jahrhunderts v. Chr., Image and Context ro, Berlin and Boston.

Heinrichs, A. (1987) 'Myth visualized: Dionysos and his circle in sixth-century Attic vase painting', in True (I987) 92-I24.

Hodder, I. (20II) 'Human-thing entanglement: towards an integrated archaeological perspective', Journal of the Royal Anthropological Institute 17, 154-77.

Hurwit, J. M. (I985) 'The Dipylon shield once more', ClAnt 4, I2I-6.

(2002) 'Reading the Chigi Vase', Hesperia 7I, I-22.

(2015) Artists and signatures in ancient Greece, Cambridge.

Jacobsthal, P. (1944) Early Celtic art, Oxford.

Karouzou, S. (I956) The Amasis Painter, Oxford.

Koehl, R. B. (I986) 'The chieftain cup and a Minoan rite of passage', JHS Io6, 99-110.

Kunze, E. (I950) Archaische Schildbänder, Olympische Forschungen II, Berlin.

Kurtz, D. (1985) 'Beazley and the connoisseurship of Greek vases', in Greek vases in the J. Paul Getty Museum 2, Malibu, CA, 237-50. 
Latour, B. (1993) We have never been modern, tr. C. Porter, London and Hemel Hempstead.

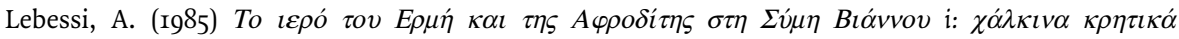

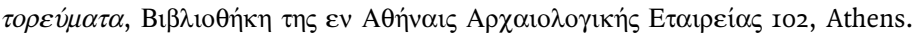

LiPuma, E. (1998) 'Modernity and forms of personhood in Melanesia', in M. Lambek and A. Strathern (eds.), Bodies and persons: comparative perspectives from Africa and Melanesia, Cambridge, 53-79.

Lissarrague, F. (I990) L'autre guerrier: archers, peltastes, cavaliers dans l'imagerie Attique, Images à l'Appui 3, Paris and Rome.

Lowenstam, S. (1993) 'The arming of Achilleus on early Greek vases', ClAnt I2, I99-218.

Lynch, K. (20I7) 'Reception, intention and Attic vases', in L. C. Nevett (ed.), Theoretical approaches to the archaeology of ancient Greece, Ann Arbor, MI, I24-42.

MacIntyre, A. (1985) After virtue: a study in moral theory, and edn, London.

Martin, S. R. (2017). The art of contact: comparative approaches to Greek and Phoenician art, Philadelphia.

Mertens, J. M. (I987) 'The Amasis Painter: artist and tradition', in True (1987) I67-83.

Moore, M. B. (I987) 'The Amasis Painter and Exekias: approaches to narrative', in True (1987) I53-67.

Morris, C. (1993) 'Hands up for the individual! The role of attribution studies in Aegean prehistory', CArch 3, 4I-66.

Nagy, G. (1990) Pindar's Homer: the lyric possession of an epic past, Baltimore and London.

(1997) 'The Shield of Achilles: ends of the Iliad and beginnings of the polis', in S. Langdon, New light on a dark age: exploring the culture of Geometric Greece, Columbia, MO and London, I94-207.

Neer, R. (1997) 'Beazley and the language of connoisseurship', Hephaistos 15, 7-30.

(2002) Style and politics in Athenian vase painting: the craft of democracy 530-460 BCE, Cambridge.

(2010) The emergence of the Classical style in Greek sculpture, Chicago and London.

Nevett, L. and J. Whitley (eds.) (2018) An age of experiment: classical archaeology transformed, McDonald Institute Monographs, Cambridge.

Nottbohm, G. (1943) 'Der Meister der grossen Dipylon-Amphora in Athen', JDAI 58, I-3I.

Oakley, J. (1998) 'Why study a Greek vase painter? A response to Whitley's "Beazley as theorist"', Antiquity 72, 209-13.

(2009) 'Greek vase painting', AJA II3, 599-627.

Osborne, R. (2018) 'Homeric imagery', in Nevett and Whitley (2018) 75-85.

Osborne, R. and J. Tanner (eds.) (2007) Art's agency and art history, Oxford and Malden, MA.

Padgett, J. M. (ed.) (2017) The Berlin Painter and his world: Athenian vase painting in the early fifth century BC, New Haven and London.

Piggott, S. (1962) The West Kennet Long Barrow: excavations 1955-56, London.

Robertson, M. (I987) 'The state of Attic vase-painting in the mid-sixth century', in True (1987) I3-28.

Rouet, P. (200I) Approaches to the study of Greek vases: Beazley and Pottier, Oxford.

Sapirstein, P. (2013) 'Painters, potters and the scale of the Attic vase-painting industry', AJA II7, 493-510.

(2014) 'Demographics and productivity in the ancient Athenian pottery industry', in J. H. Oakley (ed.),

Athenian potters and painters. Volume III, Oxford and Philadelphia, I75-86.

Saunders, D. (2017) 'The distribution of the Berlin Painter's vases', in Padgett (2017) I07-3I.

Schnapp, A. (1997) Le chasseur et la cité: chasse et érotique en Grèce ancienne, Paris.

Shanks, M. (I996) Classical archaeology of Greece: experiences of the discipline, London.

(I999) Art and the Greek city state: an interpretive archaeology, Cambridge.

Shear, T. L. (1937) 'A Spartan shield from Pylos', AEph 1937, I40-43.

Snell, B. (1953) The discovery of the mind: the Greek origins of European thought, Oxford.

(1975) Die Entdeckung des Geistes: Studien zur Entstehung des europäischen Denkens bei den Griechen, 5th edn, Göttingen.

Snodgrass, A. M. (1964) Early Greek armour and weapons, Edinburgh.

(I980) 'Towards the interpretation of the Geometric figure scenes', MDAI(A) 95, 5I-8.

(1998) Homer and the artists: text and picture in early Greek art, Cambridge.

(2006) Archaeology and the emergence of Greece: collected papers on early Greece and related topics, Edinburgh. 
Stewart, A. F. (I987) 'Narrative, genre and realism in the work of the Amasis Painter', in True (I987) 2942.

Strathern, M. (I988) The gender of the gift: problems with women and problems with society in Melanesia, Berkeley and Los Angeles.

Thomas, N. (I99I) Entangled objects: exchange, material culture and colonialism in the Pacific, Cambridge, MA.

True, M. (ed.) (I987) Papers on the Amasis Painter and his world, Malibu, CA.

Vernant, J. P. (1983) Myth and thought among the Greeks, London.

(1989) L'individu, la mort, l'amour: soi-même et l'autre en Grèce ancienne, Paris.

Vlachou, V. (ed.) (2015a) Pots, workshops and Early Iron Age society: function and role of ceramics in early Greece, Brussels.

(2015b) 'From pots to workshops: the Hirschfeld Painter and the Late Geometric I context of Attic pottery production', in Vlachou (2015a) 49-74.

von Bothmer, D. (1949) 'The arming of Achilles', Bulletin of the Museum of Fine Arts (Boston) 47, 84-90. Whitley, J. (I99I) Style and society in Dark Age Greece: the changing face of a pre-literate society, Cambridge.

(1997) 'Beazley as theorist', Antiquity 7I, 40-7.

(2006) 'Classical art and human agency: a tale of two objects in fifth-century Greece', in

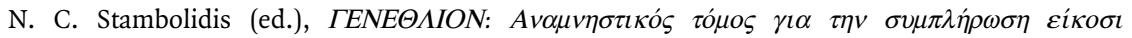

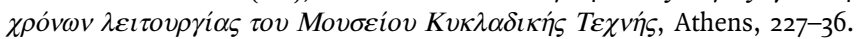

(2013) 'Homer's entangled objects: narrative, agency and personhood in and out of Iron Age texts', CArchJ 23, 395-4I6.

(2015) 'Agency, personhood and the belly-handled amphora: exchange and society in the ninthcentury Aegean', in Vlachou (2015a) 107-26.

(2018) 'The krater and the pithos: two kinds of agency', in Nevett and Whitley (2018) 59-73.

Whitley, J. and R. Madgwick (2018) 'Consuming the wild: more thoughts on the andreion', in J. Blok, F. van den Eijnde and R. Strootman (eds.), Feasting and polis institutions, Memnosyne Supplement 4I4, Leiden, I25-48.

Wilkinson, D. (2013) 'The emperor's new body: personhood, ontology and the Inka sovereign', CArchJ 23, 4I7-32.

Williams, B. (1993) Shame and necessity, Sather Classical Lectures 57, Berkeley and Los Angeles.

Williams, D. (1996) 'Refiguring Attic Red Figure: a review article', RA 1996 (2), 227-52. 